\title{
The Effect of Eyestalk Ablation on Several Immunologic Variables in Litopenaeus vannamei
}

\author{
Indriyani Nur $^{1^{*}}$, Hartina Iyen ${ }^{1}$ and Yusnaini ${ }^{1}$ \\ ${ }^{1}$ Department of Aquaculture, Faculty of Fisheries and Marine Science, Halu Oleo University, H.E.A. \\ Mokodompit Street, Anduonohu, Kendari 93232, Indonesia
}

*Correspondence :

indriyani_nur@uho.ac.id

Received : 2020-05-03

Accepted : 2020-11-14

Keywords :

Eye ablation, Hemolymph, Weight, Litopenaeus vannamei

\begin{abstract}
Eyestalk ablation is commonly inflicted upon crustacean is generally performed in captivity to induce ovarian maturation. The immunologic repercussions of the ablation have not been well understood and thus this study aims to analyze the effect of ablation on immunologic variables. Unilateral left eyestalk ablation was inflicted on shrimp samples. Shrimp immune responses were observed based on the Total Haemocyte Count (THC), Differential Haemocyte Count (DHC) composing of hyaline cell (HC) counts and granular cell (GC) counts, glucose and uric acid levels, along with the weight gains of shrimps. Observed parameters were taken twice from 10 shrimps for each of the observed and control samples (i.e., on $6 \mathrm{~h}$ and $5 \mathrm{~d}$ ). The results show that the ablated shrimps' group, after 6 hours, experienced a significant decrease in THC (3.12 $\left.\pm 0.75 \times 10^{6} \mathrm{cells} \mathrm{ml}^{-1}\right)$, but recovered after 5 days $(3.89 \pm$ $0.96 \times 10^{6}$ cells $\mathrm{ml}^{-1}$ ) and were not significantly different from the control. Meanwhile, glucose levels show a significant decrease compared to the control (35-36 $\left.\mathrm{mg} \mathrm{dL}^{-1}\right)$. Differences in DHC as well as uric acid in hemolymph were not significant. The ablated treatment did not affect the growth of vannamei. Changes occur in the physiological and immune parameters of shrimps due to the eye ablation treatment as shown by the decrease in the THC and glucose levels, especially within the early moments. However, at the end of the observation, shrimps exhibit signs of stress recovery indicated by an increase in THC close to normal.
\end{abstract}

\section{INTRODUCTION}

White shrimp (Litopenaeus vannamei) is one of the largest species of farmed shrimp in the world (Ackefors, 2009). Intensive farming systems (rearing fish or stock in high density) are often practiced to obtain higher productions of shrimps. Efforts widely applied to increase production include high stocking density, maintaining water quality, disease control, feed management technique, immunostimulation, growth hormone, and reproduction control (Flegel et al., 2008; Cobo, 2013; Ravuru and Mude, 2014; Martínez et al., 2017; Nur et al., 2019; Mulyadi et al., 2020).

Growth and reproduction control in crustaceans are achieved through eye ablation. The eyestalk ablation technique is a fast method to simultaneously acquire mature female gonads or ovaries in a short amount of time. Although the eye ablation technique is controversial, as it is 
considered to violate animal rights, the technique is still being applied in the shrimp hatchery industry, driven by the existence of target productions of larvae needed to be produced. Studies revealed that the eye ablation technique can affect metabolic physiology, molting, growth and reproduction in crustaceans such as Charybdis lucifera, Chasmagnathus granulate, Eriocheir sinensis, Oziothelphusa senex senex, Portunus sanguinolentus, and $P$. pelagicus (Cobo, 2013; Pamuru et al. 2016; Martínez et al. 2017; Ikhwanuddin et al., 2018). Eye ablation has also been applied in hatcheries of various shrimp species in cultures or enlargements including Macrobrachium rosenbergii, $M$. americanum, $M$. lanchesteri, $M$. dayanum, Astacus leptodactylus, Fenneropenaeus merguiensis, Penaeus indicus, $P$. monodon and L. vannamei (Pillai et al., 2010).

The sinus gland regulates reproductive activities in crustaceans. It can trigger an increase in ovarian size and egg maturation. Earlier studies show that the Ovary Inhibiting Factor is secreted from the sinus gland, a factor now known as Gonad Inhibiting Hormone (GIH). The sinus gland is an organ that releases $\mathrm{GIH}$, but the neurohormone itself originates from organ $\mathrm{X}$ lies near the ventral surface of the eye in the region of the medulla terminalis (Hongstrand, 1998).

In addition to accelerating molting and gonadal maturation, eye ablation is also thought to have a negative impact in instigating an increase of stress, in which stress is described as the disruption of individual homeostasis that is outside the normal limit of the shrimp (L. vannamei) (Adams, 1990). The stress response can be evaluated by behavioral observations or measuring changes in several physiological variables such as oxygen consumption, blood profile, $\mathrm{pH}$, hormones, ions, and hemocytes (Lorenzon et al., 2008) that may affect the performance of the juvenile vannamei shrimp hemolymph response. Changes in the number of hemocytes to a certain extent are usually followed by changes in the composition of the different hemocyte cells (Jussila, 1997; Hartinah et al., 2014). The parameters that can be used as an indicator of stress in crustaceans is the number of hemocytes.

Stress responses caused by changes in environmental conditions can be characterized by physiological changes in the short or long term. These responses can cause the transfer of energy resources for endocrine response, and physiologic and metabolic pathways that may damage or threaten the condition of homeostasis (Buchanan, 2000; Harper and Wolf, 2009). Under stress conditions, the fish allocate metabolic energy mainly to maintain the homeostatic state rather than growth and reproduction. Homeostatic activities, such as respiration, movement, and tissue repair. The energy needed to improve homeostasis during stress is obtained through the processes of glycogenolysis and gluconeogenesis that produce glucose (Hastuti et al., 2004).

Hemolymph has a hemocyte-cellular component and a plasma-constituted liquid component comprising various humoral factors (macromolecules of the circulatory system). The cellular immune and humoral reactions function in an integrated manner producing defensive mechanisms such as hemolymph coagulation; prophenoloxidase (ProPO) melanization system (a primary innate defense system in invertebrates), production of reactive forms of oxygen, phagocytosis and encapsulation, in which the latter two are mainly performed by hemocytes (Iwanaga and Lee, 2005). Hemocytes have an important role in the crustacean immune system and can be used to assess health based on its characteristics and defense activities against infectious agents (Jussila, 1997; Chakraborty and Ghosh, 2014). In addition, metabolic products such as glucose and uric acid in blood or body fluids can be used to determine the level of stress in crustaceans due to treatments endured during maintenance, pollutants, handling, environmental changes, and post-transportation (Jussila, 1997; Lorenzon et al., 2008; Gulec and Aksu, 
2012; Bislimi et al., 2013; Arifin et al., 2014). Therefore, in this study, the effect of eyestalk ablation on the physiological status of shrimps through observation of the hemolymph profile was done. Moreover, the possibility of stress recovery due to ablation was examined at the two different elapsed time post ablations.

\section{METHODOLOGY}

\section{Place and Time}

The study was carried out from JulyOctober 2016 at the Laboratory of Fish Health at the Faculty of Fisheries and Marine Science, Halu Oleo University, Kendari, South East Sulawesi, Indonesia.

\section{Research Material}

Tools used in this study were aquariums $(30 \times 30 \times 30 \mathrm{~cm})$, siphons, aerators, DO meter, salinity meter, thermometer, electronic blood glucoseuric acid (GCU) meter (Nesco), 1.0-ml disposable syringe (gauge 26G x 1/2"), hemocytometer (Marienfeld), hand tally counter light microscope (Olympus).

While materials used in this study were white shrimps (L. vannamei), Artemia salina, commercial feed, $\mathrm{KMnO}_{4}$ solution, anticoagulant Na-citrate 3.8\% and Giemsa solution (10\%).

\section{Research Design}

This study is an experimental quantitative study. This study used five treatments that are the percentage of red paprika in fish food. The diet treatments were $0 \%, 2 \%, 4 \%, 6 \%$, and $8 \%$. The fed was given once a day with the satiety method.

\section{Work Procedures}

\section{Experimental Shrimp}

Female white shrimps aged about 3 months, weighing 10-17 g, were acquired from a mini shrimp hatchery or farm in Bororo village, South Konawe, South East Sulawesi, Indonesia and were raised in a pond to acclimate to the experiment conditions at the laboratory of Faculty of
Fisheries and Marine Science, Kendari, South East Sulawesi, Indonesia until they reached juvenile length size of $4-5 \mathrm{~cm}$. The shrimps were fed twice a day (morning and afternoon) with Artemia salina and commercial feed combination at $5 \%$ of the shrimp body weights. A screening test on the shrimps was done before treatment to inspect their health. Healthy shrimps were later randomly distributed into two experimental group aquariums with 10 shrimps per aquarium. The condition set up refers to the optimal density in intensive cultivation ponds between 100 300 shrimps per square meter. Continuous aeration, siphoning of wastes and debris, and saline water renewal were applied to maintain clean and dissolved oxygen. During the experiment, water quality parameters were maintained at a normal level (temperature range was $28-30^{\circ} \mathrm{C}$; DO $>5 \mathrm{ppm}$ and salinity was 33-35 ppt), (Van Wyk and Scarpa, 1999).

\section{Eyestalk Ablation Method}

Unilateral eyestalk ablation was done after one-week post aquarium assignment to allow the process of adaptation to a new environment. It was conducted to maintain the vannamei shrimps to be healthy, nimble, and have a good appetite. The left eyestalk was removed with sterile sharp scissors. The risk of injury occurring due to ablation immediately dried and did not release a lot of liquid after the vannamei shrimps were soaked in a bucket filled with $5 \mathrm{ppm}$ $\mathrm{KMnO}_{4}$ solution for 15 minutes to prevent infection (Robi and Erlangga, 2014). The shrimps were later transferred into another aquarium.

\section{Rearing Activity}

Rearing was carried out for 2 weeks (from adaptation to treatment). As many as 10 shrimps from the ablated treatment group and 10 shrimps from the unablated treatment group were maintained in separate aquariums. Hemolymph was taken at six hours and 5 days after ablation. The growth rate was measured 
by weighing individual shrimp at the beginning of treatment and the end of the rearing period.

\section{Sampling of Hemolymph}

Hemolymph retrieval was carried out twice, at six hours and 5 days $(5 \times 24$ hours) after ablation. Shrimp hemolymph samples were taken individually by inserting a syringe with $3.8 \%$ Na-citrate anticoagulant, fitted with a needle into the base of the fifth pereiopod. Hemolymph was allowed to undergo capillary action and was then slowly withdrawn. Hemolymph from each treatment shrimps was taken individually for the observation of Total Hemocyte Count (THC) and the Differential Hemocyte Count (DHC), glucose, and uric acid.

\section{Observed Parameters}

The parameters of immune and stress response were measured and observed include the THC and the DHC, the hemolymph glucose, the hemolymph uric acid, as well as growth. The THC was calculated to discover the number of the shrimp's hemocyte referring to the method of Blaxhall and Daishley (1973), whereas DHC calculation was based on Martin and Graves (1995).

\section{Observation of Total Hemocyte Count (THC) and Differential Hemocyte Count (DHC) \\ Hemolymph was diluted with} anticoagulant Na-citrate (ratio 1:1) and the total hemocytes were counted using a hemocytometer (Marienfeld) and a hand tally counter using a microscope at 100x. A drop of fixed hemolymph was smeared on a slide and stained with Giemsa solution for $10 \mathrm{~min}$. Differential hemocytes were examined from 100 cells for hyaline cells (HC), granular cells (GC), and semi granular cells (SGC). They were characterized according to Tsing et al. (1989) using a microscope with a magnification of 1000x.

\section{Measurements of Hemolymph Glucose and Uric Acid Levels}

Hemolymph glucose and uric acid in the hemolymph were analyzed through the application of a drop of hemolymph to a chemically treated disposable 'test-strip' which was then placed into an electronic blood GCU meter. The glucose and uric acid levels were detected based on the reaction that occurs between the test strip and the hemolymph (Caldari-Torres et al., 2018). Their values are presented in $\mathrm{mg}$ $\mathrm{dL}^{-1}$ unit by the GCU meter (Nesco).

\section{Shrimp Growth}

Weight gain rate was measured based on the formula of Lugert et al. (2014). The absolute increase was expressed as:

$\Delta w=w_{t}-w_{i}$

Note:

$w_{t}=$ final weight/length

$w_{i}=$ weight/length

\section{Data Analysis}

The data were calculated with T-test (SPSS 23.0).

\section{RESULTS AND DISCUSSION Hemolymph Response Parameters}

Hemolymph response observations were carried out 2 times i.e. 6 hours and 5 days (5x24 hours) post eye ablation treatment. The THC level of ablated shrimp was significantly down-regulated at $6 \mathrm{~h}$, while The THC level of ablated shrimp was up-regulated gradually at $5 \mathrm{~d}$, but still lower than the control (Fig. 1). THC of ablated shrimps had a lower significance at the $6 \mathrm{~h}$ post-ablation (3.12 $\pm 0.75 \times 10^{6}$ cells $\mathrm{ml}^{-1}$ ) than unablated control group $\left(5.86 \pm 0.98 \times 10^{6}\right.$ cells $\mathrm{ml}^{-}$ ${ }^{1}$ ). However, they were recovered to be normal $\left(3.89 \pm 0.96 \times 10^{6}\right.$ cells $\left.\mathrm{ml}^{-1}\right)$, this group was not different from the control group $\left(5.16 \pm 2.20 \times 10^{6}\right.$ cells $\left.\mathrm{ml}^{-1}\right)$. 


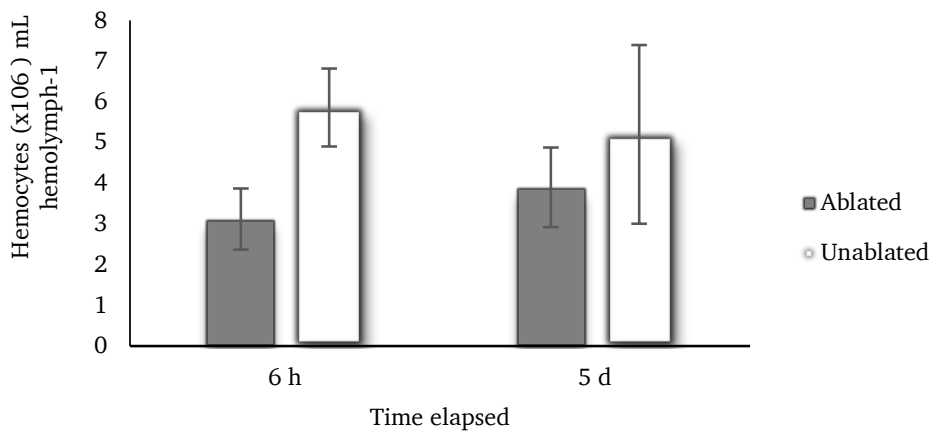

Figure 1. Total hemocytes (mean $\pm \mathrm{SD}$ ) of shrimp (L. vannamei) post-ablation, $\mathrm{N}=10$. The results show that lower data found in the eye ablation shrimp group than without eye ablation treatment in both measurement time, at first (6 hours) and the second observation $(5 \times 24$ hours $)$. Superscript indicated a significant difference $(\mathrm{p}<0.05)$ between treatments at $6 \mathrm{~h}$ post-ablation.

Three main types of circulating hemocytes were identified in shrimps test, i.e. HC, SGC, and GC hemocytes. This classification is based primarily on the cell size and presence of cytoplasmic granules in hemocytes that could be observed through staining techniques. The HC is characterized by the absence of granules, the smallest and fine cell, SGC contains a variable number of small granules, while, the granular cell is filled with fairly large granules. Overall, the DHC of ablated and unablated shrimps were not different significantly. Similarly, there was no significant difference in the HC, GC, and SGC count for any of the shrimp after $6 \mathrm{~h}$ and $5 \mathrm{~d}$ (Figure 2).

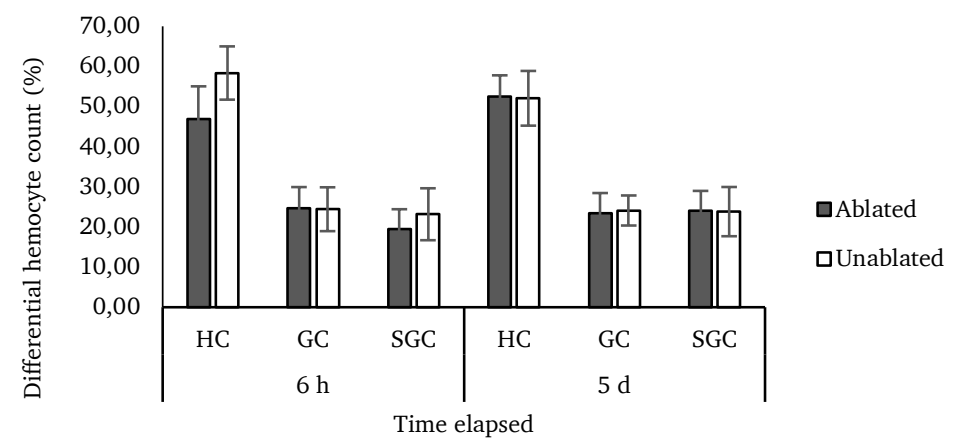

Figure 2. Three types of hemocytes, i.e. the hyaline cell (HC), the granular cell (GC) and the semigranular cell (SGC) hemocytes. There was no significant difference ( $p$ $>0.05$ ) in the DHC for any of the ablated/unablated shrimp.

Changes in the level of hemolymph glucose in vannamei shrimp treated with eye ablation based on the results of the study are presented in Fig. 3. At time $6 \mathrm{~h}$, the glucose level of ablated shrimp (108 $\mathrm{mg} \mathrm{dL}^{-1}$ ) was significantly higher than unablated one $\left(36 \mathrm{mg} \mathrm{dL}^{-1}\right)$. However, the glucose level of ablated shrimp decreased from 108 to $93 \mathrm{mg} \mathrm{dL}^{-1}$ approaching the normal level at $5 \mathrm{~d}$ post-ablation. Again, the glucose level of ablated shrimp (93 $\mathrm{mg}$ $\mathrm{dL}^{-1}$ ) was significantly higher than unablated one $\left(35 \mathrm{mg} \mathrm{dL}^{-1}\right)$ at time $5 \mathrm{~d}$ elapsed (Figure 3). 


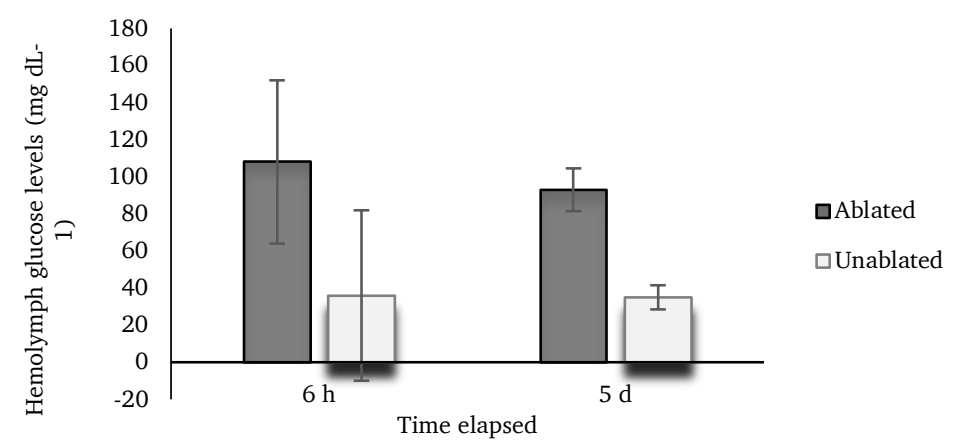

Figure 3. Glucose level (mean \pm SD) of ablated and unablated vannamei shrimp. Superscript indicated a significant difference $(\mathrm{p}<0.05)$ between treatments at $6 \mathrm{~h}$ and $5 \mathrm{~d}$ post-ablation.

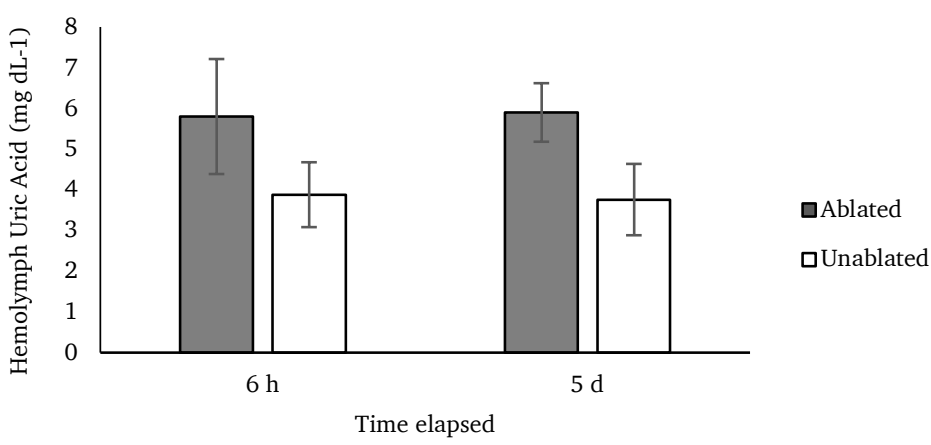

Figure 4. Uric acid level (mean $\pm \mathrm{SD}$ ) of ablated and unablated vannamei shrimp. There is no significant difference ( $p>0.05$ ) among treatments.

It was suggested that hemolymph could be used to indicate the difference in stress level or health status of vannamei shrimp after eyestalk ablation. Female shrimps after only having one eyestalk had significantly lower THC at the beginning than did normal shrimps or healthy shrimps (Fig 1). The difference in THC between ablated and unablated shrimp group could be due to stress in dying and a new atmosphere with imperfect eyesight. Meanwhile, the higher mean THC in the ablated shrimp group after $5 \mathrm{~d}$ post-ablation could have reflected stress become recovery cause the trauma has healed. There is a possibility that THC will be at a normal level if the observation is extended.

Eyestalk ablation is a significant effort to control reproduction, although it affects the physiology of shrimp (Kamaruding et al., 2018) and even broodstock survival (Magaña-Gallegos et al., 2018). Therefore, this study examined several hemolymph parameters that indicate the homeostasis of vannamei shrimp after receiving ablation. Hemocyte homeostasis is of great importance for the health of crustaceans, owing to its important role in the innate immune system (Liu et al., 2020). Crustacean hemocytes play a significant role in the immune response of the host including recognition, phagocytosis, melanization, cytotoxicity, and cell communication (Johansson et al., 2000). In this study, the mean of THC of ablated shrimp was decreased by $88 \%$ in $6 \mathrm{~h}$ elapsed time of ablation. Furthermore, at $5 \mathrm{~d}$ after ablation, THC was lower than control shrimp. Hence stress caused ablation might influence the homeostasis of the shrimp. Similar observations of depletion of hemocytes (haemocytopenia) were reported in other decapod crustaceans like lobster and crab that was caused by several things including stress, endocrine activity, environmental factors, handling, 
and bacterial infections (Matozzo and Marin, 2010; Lorenzon et al., 2008; Djai et al., 2017). The results, following the present study, that a dramatic decrease in THC can be considered as an indication of hormonal changes of the condition for the first time of ablation. This is reinforced by the statement that the endocrine system regulates the hemocyte populations in crustacean (Xu et al., 2019).

The recovery of circulating hemocytes was observed in $5 \mathrm{~d}$ elapsed time after ablation, even though it is still higher than control. It is suspected that at that time the percentage of proliferating hemocytes has gradually increased. The recovery time depends on many factors including the cause of stress, the host species, and its health status. In an experiment by Sequeira et al. (1996) with kuruma shrimp $P$. japonicus injected with LPS, it was observed a significantly increased percentage of proliferating hemocytes $72 \mathrm{~h}$ post-injection.

Three distinct types of hemocytes in decapod crustaceans are primarily based on the presence of cytoplasmic granules into hyaline cells, semigranular cells, and granular cells. Each cell type has a different function in immunity, however, each species of crustaceans exhibited variable immune activities. In crayfish and crab, for example, the hyaline cells are mostly involved in phagocytosis, the semigranular cells are active in encapsulation, while the granular cells participate in storage and release of the prophenoloxidase proPO system and cytotoxicity mechanism (Johansson et al., 2000). Meanwhile, the main phagocytic capabilities of granular and semigranular cells were observed in Macrobrachium rosenbergii, and Penaeus monodon (Sung et al., 2000; Chai et al., 2012).

$\mathrm{HC}$ levels were lower at $6 \mathrm{~h}$ than at $5 \mathrm{~d}$ elapsed time of ablation but did not differ significantly (Fig 2). The slight decrease in $\mathrm{HC}$ of ablated shrimp at $6 \mathrm{~h}$ post-ablation is thought to be associated with phagocytosis. The injured eye allows the entrance of foreign material into the shrimp body. The migration of hemocytes to the injection site to phagocytize antigens and aggregation of cells is a form of defense response of crustacean (Van de Braak et al., 2002). DHC values at the twotime measurements did not show significant differences in both ablated and unablated shrimps, this seems to be following the results of the study of Van de Braak et al. (2002) that high variations in THC after shrimps treatment, are not accompanied by significant changes in DHC. DHC is more frequently defined as a less useful stress indicator or the health status of crustaceans.

Stress is an animal disorder due to adverse conditions. If the glucose level in shrimp exceeds $150 \mathrm{mg} \mathrm{dL}^{-1}$, this indicates that the shrimp is stressed and requires higher energy (Cuzon et al., 2004). Mulyadi et al. (2020) found that the glucose in hemolymph rose up to $107 \mathrm{mg}$ $\mathrm{dL}^{-1}$ due to infection with vibriosis. In this study, at the moment of stress caused eyestalk ablation, there is a rise in the glucose of hemolymph (Fig 3). These mechanisms revealed that the ablated shrimp group was vulnerable to stress, in line with the statement of Cui et al. (2017) that eyestalk removal has also induced a significant decrease in glucose levels, indicating that the eyestalk hormone is involved in glucose metabolism to fulfill energy requirements under stress conditions. Blood glucose levels are set to always be in a stable condition in the body through the homeostatic process (Adisuwirjo et al., 2001). Excessive deviation from the normal either too high or too low indicating the disruption of homeostasis, lead to tissue damage such as tissue dehydration, and loss of essential ions, besides its effect on growth (Utari et al., 2013).

The concentration of uric acid in the hemolymph is a reliable indicator of the physiological events occurring after molting. An increase in uric acid concentration after molting in a species of insect was correlated with the degeneration of the molting, muscle breakdown is causing the concentration of uric acid in the hemolymph to increase at 
this time (Barrett and Friend, 1966). It can be explained that uric acid can be derived from autolysis proteins. Nitrogen metabolism end products are found in small concentrations in the hemolymph. (Cheng et al., 2004). Moreover, it was found that uric acid, and urea are related to the excretion of shrimp due to higher salinity levels (Lee and Chen, 2003). In this study, the uric acid level found in hemolymph statistically was not significantly different between ablated and unablated shrimps. However, descriptively, the data showed a higher level in the ablated shrimp group compared to the unablated one both in 6 $\mathrm{h}$ and $5 \mathrm{~d}$. This might be due to the small sample sizes, larger sample sizes give more reliable results that there is a difference (or effect) in the population (Alwi, 2012).

\section{Weight Gain Rate}

A higher weight increase was found in those that were unablated shrimp group compared to ablated one.

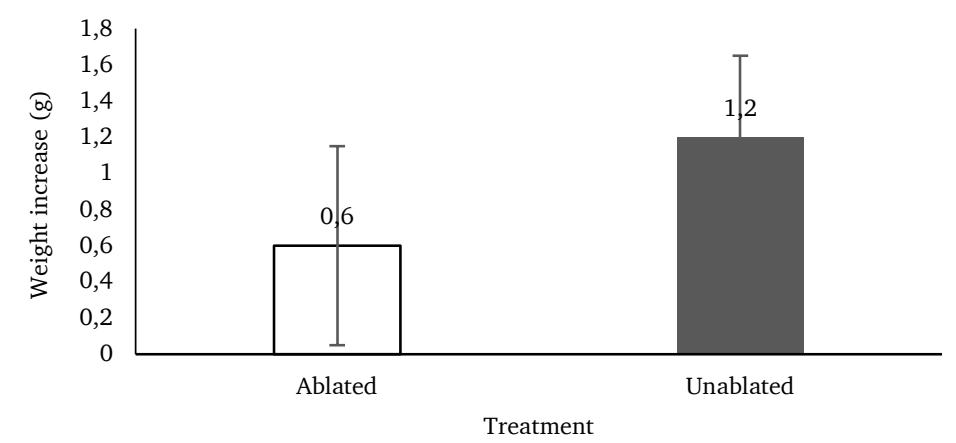

Figure 5. Weight increase of ablated and unablated vannamei shrimp. There was no significant difference $(p>0.05)$ in the growth for any of the ablated/unablated shrimp.

The average growth results of vannamei shrimp weight during this study show that vannamei shrimp growth in eye ablation treatment is lower $(0.6 \mathrm{~g})$ compared to treatment without eye ablation namely (1.2 g) (Fig 5). It is suspected that shrimp in the eye ablation treatment is still in a stress period that disrupts the metabolic process so that the energy obtained from the feed is used to improve the physiological conditions or for maintenance. This is in line with the statement of Zarain-Herzberg et al. (2010), that stress will affect the growth of vannamei shrimp. In addition, Ponnuchamy et al. (1981) argued that high stress results in mortality. They found that bilateral eyestalk ablation results in high mortality in the freshwater prawn $M$. lanchesteri, whereas unilateral eyestalk ablated prawns showed a high survival rate.

\section{CONCLUSION}

In conclusion, decreased THC and increased glucose levels could be an indication of either increasing stress or adverse health effects of the female broodstock shrimp under eyestalk ablation. On the other hand, DHC and uric acid levels were less useful as indicators of stress or health status. Hemocytes and glucose levels may therefore be useful tools for assessing the immune response of vannamei shrimp.

\section{ACKNOWLEDGMENT}

Thanks are due to the staff of Fish Health Laboratory, Halu Oleo University for their technical assistance. 


\section{REFERENCES}

Ackefors, H., 2009. The evolution of a worldwide shrimp industry. World Aquaculture, pp.46-55. https:// www.was.org/magazine/ArticleCon tent.aspx?Id $=592$

Adams, S.M., 1990. Status and biological indicator for evaluating the effects of stress on fish. biological indicator of stress in fish. In: Adams, S.M. (ed.) American Fisheries Symposium, pp.1- 8.

Adisuwirjo, Sutrisno, D. and Setyawati, S.J.A., 2001. Dasar Fisiologi Ternak. Fakultas Peternakan. Universitas Jenderal Soedirman. Purwokerto.

Alwi, I., 2012. Kriteria empirik dalam menentukan ukuran sampel pada pengujian hipotesis statistika dan analisis butir. Jurnal Formatif, 2(2), pp.140-148. http://dx.doi.org/10. 30998/formatif.v2i2.95

Arifin, M.Y., Supriyono, E. dan Widanarni, 2014. Total hemosit, glukosa, dan survival rate udang mantis (Harpiosquilla raphide) pasca transportasi dengan dua sistem yang berbeda. J. Kelautan Nasional, 9(2), pp.1-9. https://doi.org/10.15578/ jkn.v9i2.6207

Barrett, F.M. and Friend, W.G., 1966. Studies on the uric acid concentration in the haemolymph of fifth-instar larvae of Rhodnius Prolixus (Stål) during growth and metamorphosis. Journal of Insect Physiology, 12(1), pp.1-7. https:// doi.org/10.1016/0022-1910(66)90 059-X

Bislimi, K., Behluli, A., Halili, J., Mazreku, I., Osmanil, F. and Halili, F., 2013. Comparative analysis of some biochemical parameters in hemolymph of garden snail Helix pomatia of the Kastriot and Ferizaj Regions, Kosovo. Int. J. of Engineering and Applied Sciences, 4(6), pp.11-18. http://eaas-journal. org/survey/userfiles/files/v4i602\% 20Maths\%20\&\%20Natural\%20Scie nce.pdf
Blaxhall, P.C. and Daisley, K.W., 1973. Routine haematological methods for use with fish blood. Journal Fish Biology, 5(6), pp.577-581. https:// doi.org/10.1111/j.1095-8649.1973. tb04510.x

Buchanan, K.L., 2000. Stress and the evolution of condition-dependent signals. Trends in Ecology and Evolution, 15, pp.156-160. https:// doi.org/10.1016/S0169-5347(99)0 1812-1

Caldari-Torres, C., Banta-Long, W., Bruss, A., Choi, E., Fiegel, H. Jollis, M.S., Ly, S. and Viswanathan, S., 2018. Hemolymph glucose levels as a measure of crayfish stress: a methodology using a human glucometer. The FASEB Journal, 32(S1), lb224. https://doi.org/10. 1096/fasebj.2018.32.1_supplement $.1 \mathrm{~b} 224$

Chai, Y.M., Zhu, Q., Yu, S.S., Zhao, X.F. and Wang, J.X., 2012. A novel protein with a fibrinogen-like domain involved in the innate immune response of Marsupenaeus japonicus. Fish \& Shellfish Immunology, 32(2), pp.307-315. https://doi.org/10.1016/j.fsi.2011. 11.020

Chakraborty, S. and Ghosh, U., 2014. In vivo immunological changes occurring at different time intervals in white spot syndrome virus infected shrimp, treated with antiWSSV drug derived from marine plants. International Journal of Basic and Applied Virology, 3(1), pp.0115. DOI : 10.5829/idosi.ijbav.2014. 3.1.81254

Cheng S.Y., W.C. Lee, W.C., Shieh, L.W. and Chen, J.C., 2004. Increased production and excretion of urea in the kuruma shrimp (Marsupenaeus japonicus) exposed to combined environments of increased ammonia and nitrite. Archives of Environmental Contamination and Toxicology, 47, pp.352-362. https:// doi.org/10.1007/s00244-004-31902 
Cobo, M.L., 2013. Intensification of white shrimp Litopenaeus vannamei (Boone) larviculture. Ph.D. Thesis, Ghent University, Belgium. http:// hdl.handle.net/1854/LU-3172967

Cui, Y., Ren, X., Li, J., Zhai, Q., Feng, Y., $\mathrm{Xu}, \mathrm{Y}$. and Ma, L., 2017. Effects of ammonia-N stress on metabolic and immune function via the neuroendocrine system in Litopenaeus vannamei. Fish \& Shellfish Immunology, 64, pp.270275. https://doi.org/10.1016/j.fsi. 2017.03.028

Cuzon, G., Lawrence, A., Gaxiola, G., Rosas, C. and Guillaume, J., 2004. Nutrition of Litopenaeus vannamei reared in tanks or in ponds. Aquaculture. 235(1-4), pp.513-551. https://doi.org/10.1016/j.aquacult ure.2003.12.022

Djai, S., Supriyono, E., Nirmala, K. and Adiyana, K., 2017. Total hemocyte count and hemolymph glucose concentration response of spiny lobster Panulirus homarus on ratio of shelter. Jurnal Ilmu dan Teknologi Kelautan Tropis, 9(1), pp.125-133. https://doi.org/10.29244/jitkt.v9i1 .17923

Flegel, T.W., Lightner, D.V., Lo, C.F. and Owens, L., 2008. Shrimp disease control: Past, present and future, pp.355-378. In: Bondad-Reantaso, M.G., Mohan, C.V., Crumlish, M. and Subasinghe, R.P. (eds.). Diseases in Asian Aquaculture VI. Fish Health Section, Asian Fisheries Society, Manila, Philippines. pp 505. http://www.fhs-afs.net/daa_vi_files /27.pdf

Gulec, A.K. and Aksu, O., 2012. Effects of handling on physiological profiles in Turkish crayfish Astacus leptodactylus. World J. of Fish and Marine Sciences, 4(6), pp.684-688. DOI : 10.5829/idosi.wjfms.2012.04. 06.65103

Harper, C. and Wolf, J.C., 2009. Morphologic effects of the stress response in fish. ILAR Journal,
50(4), pp.387-396. https://doi.org/ 10.1093/ilar.50.4.387

Hartinah, Sennung, L.P.L. and Hamal, R., 2014. Performa Jumlah dan Diferensiasi Sel Hemosit Juvenil Udang Windu (Penaeus Monodon Fabr.) pada Pemeliharaan dengan Tingkat Teknologi Budidaya yang Berbeda. bionature, 15(2), pp.104110. https://doi.org/10.35580/ bionature.v15i2.1556

Hastuti, S., Mokoginta, I., Dana, D. and Sutardi, T., 2004. Resistensi terhadap stres dan respons imunitas ikan gurami (Osphronemus gouramy, Lac.) yang diberi pakan mengandung kromium-ragi. Jurnal Ilmu-Ilmu Perairan dan Perikanan Indonesia, 11(1), pp.15-21. https:// journal.ipb.ac.id/index.php/jippi/ar ticle/view/7045/5442

Hongstrand, C., 1998. Comparison Physiology. Endocrinology (Chapter H), p.17.

Ikhwanuddin, M., Adnan, M., Mohamad, S. and Abol-Munafi, A.B., 2019. Effect of eyestalk ablation on the ovarian maturation stages of blue swimming crab, Portunus pelagicus. Asian Journal of Biological Sciences, 12(3), pp.437-441. https://doi.org/ 10.3923/ajbs.2019.437.441

Iwanaga, S. and Lee, B.L., 2005. Recent advances in the innate immunity of invertebrate animals. BMB Reports, 38(2), pp.128-150. https://doi.org/ 10.5483/BMBRep.2005.38.2.128

Johansson, M.W., Keyser, P., Sritunyalucksana, K. and Söderhäll, K., 2000. Crustacean haemocytes and haematopoiesis. Aquaculture, 191(1-3), pp.45-52. https://doi. org/10.1016/S0044-8486(00)0041 8-X

Jussila, J., 1997. Physiological responses of Astacid and Parastacid crayfishes (Crustacea: Decapoda) to conditions of intensive culture (p. 140). Western Australia: University of Kuopio.

Kamaruding, N.A., Ismail, N. and Ikhwanuddin, M., 2018. Physiological effect of eyestalk 
ablation on nutrient utilization and plasma protein expression in the female giant freshwater prawn (Macrobrachium rosenbergii) during different molting cycles. Journal of Shellfish Research, 37(5), pp.11131120. https://doi.org/10.2983/035 .037 .0523

Lee, W.C. and Chen, J.C., 2003. Hemolymph ammonia, urea and uric acid levels and nitrogenous excretion of Marsupenaeus japonicas at different salinity levels. Journal of Experimental Marine Biology and Ecology, 288(1), pp.39-49. https:// doi.org/10.1016/S0022-0981(02)0 0597-X

Liu, S., Zheng, S.C., Li, Y.L., Li, J. and Liu H.P., 2020. Hemocyte-mediated phagocytosis in crustaceans. Frontiers in Immunology, 11(268), pp.1-9. https://doi.org/10.3389/ fimmu.2020.00268

Lorenzon, S., Giulianini, P.G., Libralato, S., Martinis, M. and Ferrero, E.A., 2008. Stress effect of two different transport systems on the physiological profiles of the crab Cancer pagurus. Aquaculture, 278(14), pp.156-163. https://doi.org/10. 1016/j.aquaculture.2008.03.011

Lugert, V., Thaller, G., Tetens, J., Schulz, C. and Krieter, J., 2014. A review on fish growth calculation: multiple functions in fish production and their specific application. Reviews in Aquaculture, 8(1), pp.1-13. https:// doi.org/10.1111/raq.12071

Magaña-Gallegos, E., Bautista-Bautista, M., González-Zuñiga, L.M., Arevalo, M., Cuzon, G. and Gaxiola, G., 2018. Does unilateral eyestalk ablation affect the quality of the larvae of the pink shrimp Farfantepenaeus brasiliensis (Letreille, 1817) (Decapoda: Dendrobranchiata: Penaeidae)? Journal of Crustacean Biology, 38(4), pp.401-406. https:// doi.org/10.1093/jcbiol/ruy043

Martin, G.G. and Graves, B.L., 1985. Structure and classification of shrimp hemocytes. Journal of
Morphology, 185(3), pp.339-348. https://doi.org/10.1002/jmor.1051 850306

Martínez, R., Carpio, Y., Arenal, A., Lugo, J.M., Morales, R., Martín, L., Rodríguez, R. F., Acosta, J., Morales, A., Duconge, J. and Estrada, M.P., 2017. Significant improvement of shrimp growth performance by growth hormone-releasing peptide6 immersion treatments. Aquaculture Research, pp.1-14. https://doi.org/10.1111/are.13286

Matozzo, V. and Marin, M.G., 2010. First cytochemical study of hemocytes from the crab Carcinus aestuarii (Crustacea, Decapoda). European journal of histochemistry, 54(e9), p.44-49. https://doi.org/10.4081/ ejh.2010.e9

Mulyadi, Nur, I. and Iba, W., 2020. Efficacy of seaweed (Sargassum sp.) extract to prevent vibriosis in white shrimp (Litopenaeus vannamei) juvenile. International Journal of Zoological Research, 16(1), pp.1-11. https://doi.org/10.3923/ijzr.2020. 1.11

Nur, I., Santi and Kurnia, A., 2019. Efficacy of guava (Psidium guajava) leaves extract to prevent vibriosis in white shrimp (Litopenaeus vannamei). Research Journal of Medicinal Plants, 13(4), pp.136-144. https://doi.org/10.3923/rjmp.2019 .136 .144

Pamuru R.R., Hosamani, N. and Pamanji, S.R., 2016. Natural and induced (eyestalk ablation) molt cycle in freshwater rice field crab Oziothelphusa senex senex. Journal of Aquaculture Research \& Development, 7, pp.424-427. https: //doi.org/10.4172/2155-9546.100 0424

Pillai, B.R., Sahoo, L., Sahu, S., Vijayakumar, S.M. and Sahu, S., 2010. Effect of unilateral ablation on ovarian maturation and occurance of berried female in Macrobrachium rosenbergii (de Man). Indian Journal of Fisheries, 57(4), pp.77-80. http:// 
epubs.icar.org.in/ejournal/index.ph p/IJF/article/view/6740/2554

Ponnuchamy, R., Ravichandra Reddy, S. and Shakuntala, K., 1981. Effects of eyestalk ablation on growth and food conversion efficiency of the freshwater prawn Macrobrachium lanchesteri (de Man). Hydrobiologia 77, pp.77-80. https://doi.org/10. 1007/BF00006391

Ravuru, D.B. and Mude, J.N., 2014. Effect of density on growth and production of Litopenaeus vannamei of brackish water culture system in summer season with artificial diet in Prakasam District, India. American International Journal of Research in Formal, Applied, \& Natural Sciences, 5(1), pp.10-13. http://www.iasir. net/

Robi, M. and Erlangga, 2014. Pengaruh ablasi mata terhadap kecepatan kematangan gonad kepiting bakau (Sylla serrata) betina. Acta Aquatica, 1(1), pp.14-19. https://doi.org/10. 29103/aa.v1i1.292

Sequeira, T., Tavares, D. and AralaChaves, M., 1996. Evidence for circulating hemocyte proliferation in the shrimp Penaeus japonicus. Developmental \& Comparative Immunology, 20(2), pp.97-104. https://doi.org/10.1016/0145-305 $\mathrm{x}(96) 00001-8$

Sung, H.H., Hwang, S.F. and Tasi, F.M., 2000. Responses of giant freshwater prawn (Macrobrachium rosenbergii) to challenge by two strains of Aeromonas spp. Journal of Invertebrate Pathology, 76(4), pp.278-84. https://doi.org/10.100 6/jipa.2000.4981

Tsing, A., Arcier, J.M. and Brehélin, M., 1989. Hemocytes of penaeid and palaemonid shrimps: morphology cytochemistry, and hemograms. Journal of Invertebrate Pathology, 53(1), pp.64-77. https://doi.org/ 10.1016/0022-2011(89)90075-X

Utari, A.G., Irianti, N. and Mugiyono, S., 2013. Total protein plasma and blood glucose level in manila ducks fed with different protein and metabolic energy. Jurnal Ilmiah Peternakan, 1(3), pp.1037-1042. https://www.e-jurnal.com/2016/10 /kadar-total-plasma-dan-glukosadarah.html

Van de Braak, C.B.T., Botterblom, M.H.A., Taverne, N., van Muiswinkel, W.B., Rombout, J.H.W.M. and van der Knaap, W.P.W., 2002. The roles of haemocytes and the lymphoid organ in the clearance of injected Vibrio bacteria in Penaeus monodon shrimp. Fish \& Shellfish Immunology, 13(4), pp.293-309. https://doi.org/10.100 6/fsim.2002.0409

Van Wyk, P. and Scarpa, J., 1999. Water quality and management. p.128-138. In: Farming marine shrimp in recirculating freshwater systems. Van Wyk, P. et al., (eds). Florida Department of Agriculture and Consumer Services, Tallahassee, FL, USA.

Xu, L., Pan, L., Zhang, X. and Wei, C., 2019. Effects of crustacean hyperglycemic hormone $(\mathrm{CHH})$ on regulation of hemocyte intracellular signaling pathways and phagocytosis in white shrimp Litopenaeus vannamei. Fish \& Shellfish Immunology, 93, pp.559566. https://doi.org/10.1016/j.fsi. 2019.07.051

Zarain-Herzberg, M., Fraga, I. and Hernandew-Llamas, A., 2010. Advances in intensifying the cultivation of the shrimp Litopenaeus vannamei in seawater floating cages. Aquaculture. 300(1), pp.87-92. https://doi.org/10.1016/j.aquacult ure.2009.12.016 